\title{
BAHAN AJAR KESETIMBANGAN DAN DINAMIKA ROTASI DENGAN PENDEKATAN FILOSOFIS
}

\author{
Faikotun Nikmah ${ }^{1 *}$; Agus Yulianto ${ }^{2)}$, Siti Wahyuni ${ }^{2)}$. \\ 1) Program Studi Pendidikan Fisika, Pascasarjana Universitas Negeri Semarang, \\ 2) Kampus Pascasarjana Unnes Jl. Kelud Utara III Semarang 50237 \\ e-mail: faikotun9nikmah@gmail.com.
}

\begin{abstract}
The teaching material of equilibrium and rotational dynamics in this study developed using a philosophical approach. Teaching materials compiled contain elements of ontology, epistemology, and axiology. The research conducted using the research and development method through 9 stages, namely the study of potential and problems, data collection, product design, design validation 1 , revision stage 1 , design validation 2 , revision stage 2 , limited trials, and final product. The feasibility test of teaching materials based on two expert validators and students' responses using a questionnaire. The results of the study indicate teaching materials included in the feasible category, with an average value of $80.83 \%$. The results of students' responses agreed type, with an average of $79.41 \%$. Thus it was concluded that the entire instructional content of equilibrium and rotational dynamics developed was suitable for use in learning.
\end{abstract}

Keywords: Teaching materials, epistemological approaches, ontology, axiology

\begin{abstract}
Abstrak
Bahan ajar meteri kesetimbangan dan dinamika rotasi dalam penelitian ini dikembangkan dengan menggunakan pendekatan filosofis. Bahan ajar yang disusun mengandung unsur-unsur ontologi, epistemologi, dan aksiologi. Penelitian dilakukan dengan metode researd and developmnet melalui 9 tahap, yaitu potensi dan masalah, pengumpulan data, desain produk, validasi desain 1, revisi tahap 1, validasi desain 2, revisi tahap 2, uji coba terbatas dan produk akhir. Uji kelayakan bahan ajar didasarkan pada penilaian dua validator ahli dan respons peserta didik melalui angket. Hasil penelitian ini menunjukkan bahwa berdasar hasil penilaian validator 1 dan 2 bahan ajar masuk dalam kategori layak, dengan nilai rata-rata $80,83 \%$. Adapun hasil respons peserta didik terhadap penggunaan bahan ajar dalam pembelajaran adalah masuk dalam kategori setuju, dengan rata-rata sebesar $79,41 \%$. Dengan demikian disimpulkan bahwa keseluruhan bahan ajar materi kesetimbangan dan dinamika rotasi yang dikembangkan layak untuk digunakan dalam pembelajaran.
\end{abstract}

Kata Kunci: Bahan ajar, pendekatan epistemologi, ontologi, aksiologi

\section{PENDAHULUAN}

Fisika bukan hanya berisikan pengetahuan konsep dan rumus matematis yang harus dipelajari peserta didik, namun juga pemahaman yang dapat diaplikasikan dalam memecahkan permasalahan kehidupan sehari-hari (Toharuddin et al. 2011). Pengetahuan dan pemahaman merupakan hal dasar yang dimiliki peserta didik dalam proses pembelajaran. Kemajuan suatu bangsa dapat diukur dari tingkat pengetahuan pendidik mengenai metode, sumber belajar, teori pengajaran dan orientasi pengajaran yang modern (Alelaimat \& Ghoneem, 2012). Oleh karena itu, dibutuhkan sumber belajar sebagai salah satu media untuk meningkatkan pembelajaran peserta didik di era modern ini. 
Salah satu dari sumber belajar adalah bahan ajar. Sumber belajar jenis ini memiliki peran penting dalam proses pembelajaran yaitu membantu tercapainya tujuan pembelajaran. Banyak ahli telah mendefinisikan pengertian bahan ajar, di antaranya Kiong et al. (2012). Dia menyatakan bahwa bahan ajar adalah serangkaian kegiatan belajar yang dirancang dengan hati-hati untuk membantu peserta didik mencapai tujuan pembelajaran dan memberikan informasi pengetahuan. Fungsi dari bahan ajar yaitu sebagai pedoman bagi peserta didik baik dalam konteks pembelajaran mandiri atau pertemuan kelas tatap muka dengan metode pembelajaran, penilaian dan tugas akhir (Prayekti, 2017).

Sudah menjadi berita yang populer bahwa sebagian materi fisika kurang disenangi oleh peserta didik karena dianggapnya sulit dipahami. Hal ini sejalan dengan penelitian yang dilakukan oleh Alias et al. (2013), bahwa fisika selalu dianggap sebagai subjek yang paling sulit karena melibatkan konsep abstrak. Salah satu materi fisika yang dianggap sulit oleh peserta didik yaitu kesetimbangan dan dinamika rotasi. Hasil penelitian Sarkity et al. (2016) menyatakan bahwa lebih dari 50\% peserta didik mengalami kesulitan dalam mempelajari kesetimbangan dan dinamika rotasi. Kesulitan tersebut menyebabkan pehaman peserta didik menjadi sangat rendah. Lebih parah lagi, rendahnya pemahaman itu juga menyebabkan peserta didik mengalami kesulitan dalam memecahkan berbagai problem terkait dengan materi kesetimbangan dan dinamika rotasi. Peserta didik juga mengalami kesulitan dalam mengerjakan soal-soal yang biasa digunakan untuk mengukur pemahaman.

Di antara pokok penyebab materi kesetimbangan dan dinamika rotasi sulit dipahami adalah karena disajikan secara prakmatis. Banyak susunan bahan ajar hanya terdiri dari definisi, kemudian penyajian rumus, selanjutnya latihan soal. Konsep dari materi yang dipelajari hanya dikaji pada tingkat permukaan. Karenanya soal-soal yang tingkat kesulitannya sedang atau tinggi menjadi sulit dipecahkan; apalagi untuk kasus-kasus yang lebih kompleks.

Berbagai masalah tersebut di atas, maka dibutuhkan solusi yang tepat untuk mengatasinya. Bahan ajar harus disajikan sedemikian hingga menumbuhkan pemahan yang mendalam pada peserta didik. Pemahaman peserta didik harus sampai pada konsep yang mendasar dan mendalam. Pilihan yang paling baik adalah menyusun bahan ajar dengan pendekatan filosofis atau filsafat. Kajian materi fisika dengan pendekatan filosofis memungkinkan peserta didik berpikir secara mendalam tentang materi yang dipelajari sehingga diperoleh pemahaman yang baik. Kajian filosofis materi fisika mengandung unsurunsur ontologi, epistimologi dan aksiologi. Ontologi adalah ilmu yang mempelajari tentang hakikat sesuatu yang berwujud (yang ada) dengan berdasarkan pada penalaran logis (Adib, 2018). Epistemologis adalah kebenaran fakta/kenyataan dari sudut pandang mengapa dan bagaimana fakta itu benar yang dapat diverifikasi atau dibuktikan kembali kebenarannya (Sumarto, 2017); sedangkan aksiologi adalah ilmu yang membicarakan tentang orientasi atau nilai suatu kehidupan. (Adib, 2018). Pada prinsipnya setiap sains dibangun di atas tiga dasar utama, yaitu fondasi atau pilar ontologi, epistemologi, dan aksiologi (Purwanto, 2012).

Berdasarkan permasalahan dan pemikiran solutif di atas, penelitian mencoba mengatasi kesulitan tersebut dengan mengembangkan bahan ajar kesetimbangan dan dinamika dengan pendekatan filosofis yaitu dengan mengandung unsur epistemologi, ontologi, dan aksiologi.

\section{METODE}

Penelitian pengembangan bahan ajar ini dilakukan melalui beberapa tahapan. Tahapan awal adalah mengidentifikasi potensi dan masalah, diikuti dengan tahapan pengumpulan data serta tahapan desain produk. Tahapan selanjutnya adalah validasi desain 1 , kemudian diikuti dengan tahapan revisi 1. Setelah tahapan validasi desain 2 serta revisi tahap 2, tahapan selanjutnya adalah uji coba terbatas dan produk akhir (Sugiyono, 2012). Uji coba bahan ajar 
dilakukan di SMA Negeri 14 Semarang kelas XI MIPA 3 tahun pelajaran 2019/2020 dengan jumlah peserta didik sebanyak 34 siswa.

Penelitian ini dilakukan secara deskriptif kuantitatif dan kualitatif. Berdasar data-data yang dikuantitatifkan, bahan ajar yang telah divalidasi oleh validator dideskripsikan secara kualitatis untuk memperoleh penjelasannya. Demikian juga untuk respons dari peserta didik terhadap produk bahan ajar. Kuantisasi deskripsi bahan ajar diwujudkan dalam bentuk skor yang diperoleh dari lembar penilaian oleh validator dan angket oleh peserta didik. Teknik pengambilan sampel pada penelitian ini adalah random sampling.

Data penelitian ini dikumpulkan dengan teknik angket dan lembar validasi. Metode validasi yang digunakan adalah validasi isi, bahasa, grafis, dan penyajian. Lembar validasi digunakan untuk mengukur validitas bahan ajar sebelum dilakukan penelitian. Angket digunakan untuk mengetahui respons peserta didik terhadap bahan ajar fisika yang dikembangkan. Untuk menetapkan kelayakan bahan ajar, skor penilaian oleh validator dan angket respons peserta didik dihitung menggunakan persamaan berikut ini.

$$
\text { Skor rata }- \text { rata }=\frac{\text { Jumlah skor yang diperoleh }}{\text { Jumlah skor maksimum }} \times 100 \%
$$

Kriteria kelayakan bahan ajar tersebut didasarkan pada skala Likert, kemudian diinterpretasikan pada Tabel 1.

Tabel 1. Kriteria Penilaian Bahan Ajar

\begin{tabular}{cc}
\hline Persentase (\%) & Kriteria \\
\hline$\overline{\mathrm{X}}<20$ & Sangat tidak layak \\
$21 \leq \overline{\mathrm{X}} \leq 40$ & Kurang layak \\
$41 \leq \overline{\mathrm{X}} \leq 60$ & Cukup layak \\
$61 \leq \overline{\mathrm{X}} \leq 80$ & Layak \\
$81 \leq \overline{\mathrm{X}} \leq 100$ & Sangat layak \\
\hline & Sumber: Riduwan (2013).
\end{tabular}

Sedangkan kriteria hasil respons peserta didik terhadap bahan ajar dapat dilihat kriteria sesuai dengan Tabel 2.

Tabel 2. Kriteria Respons Peserta Didik

\begin{tabular}{cc}
\hline Rata-rata Skor & Kriteria \\
\hline $81 \leq \mathrm{Na} \leq 100$ & Sangat setuju \\
$61 \leq \mathrm{Na} \leq 80$ & Setuju \\
$41 \leq \mathrm{Na} \leq 60$ & Ragu-ragu \\
$21 \leq \mathrm{Na} \leq 40$ & Tidak setuju \\
$\mathrm{Na}<20$ & Sangat tidak setuju \\
\hline & Sumber: Arikunto (2010).
\end{tabular}

Mutu bahan ajar materi fisika dengan pendekatan ontologi, epistimologi, dan aksiologi ini ditentukan melalui penilaian validasi minimal memiliki kategori layak dan angket respons peserta didik dengan kriteria setuju.

Menurut Purwanto (2012), sajian materi kesetimbangan dan dinamika rotasi yang dikaji menggunakan pendekatan epistimologi, ontologi, dan aksiologi adalah sebagai berikut: 1) Epistemologi Besaran-besaran dalam Kesetimbangan Benda Tegar dan Dinamika Rotasi

Epistemologi berhubungan dengan cara dan sumber suatu pengetahuan, dengan apa atau bagaimana suatu pengetahuan dapat diperoleh. 
a) Kesetimbangan Benda Tegar

Benda tegar dapat didefinisikan sebagai benda yang jarak serta orientasi relatif semua partikel penyusun benda selalu tetap. Pada pembahasan mekanika partikel, gerak benda tegar dapat diwakili oleh gerak titik pusat massanya. Pada kondisi tertentu benda tegar akan mengalami kesetimbangan, yaitu jika tidak ada gaya atau momen gaya yang bekerja padanya. Secara mekanis kesetimbangan benda tegar dapat dibagi menjadi dua, yaitu kesetimbangan statis dan kesetimbangan dinamis. Berdasar jenis geraknya, kesetimbangan benda juga dibagi menjadi dua, yaitu kesetimbangan translasi dan kesetimbangan rotasi.

Kesetimbangan translasi terjadi bila tidak ada resultan gaya yang bekerja pada benda, atau $\sum F=0$. Jika pada awalnya benda sudah bergerak dengan kecepatan tertentu, maka benda akan tetap bergerak dengan kecepatan tersebut. Sementara kesetimbangan rotasi terjadi bila momen gaya yang bekerja pada benda sama dengan nol, atau $\sum \tau=0$. Benda tegar akan berubah kesetimbangan translasionalnya bila mendapatkan gaya, yaitu berupa tarikan atau dorongan yang bekerja pada titik pusat massa. Bila gaya yang bekerja tidak pada pusat massa serta menghasilkan momen gaya atau torsi, maka yang berubah adalah kesetimbangan rotasi. Secara mendasar dapat dikatakan bahwa gaya adalah faktor yang mengubah gerak benda secara translasional; sedangkan momen gaya menyebabkan perubahan gerak benda secara rotasional.

b) Pusat Massa

Pusat massa sebuah benda dapat diartikan sebagai titik di mana gaya total dapat dianggap bekerja untuk menentukan gerak translasi benda sebagai satu kesatuan. Contoh letak dari pusat massa benda yang rapat massanya seragam dapat dilihat pada Gambar 1 (Giancoli, 2014).

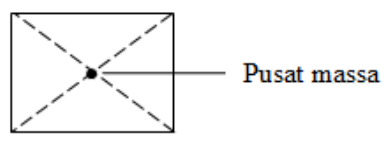

Gambar 1. Letak Pusat Massa pada Benda

c) Momen Gaya

Momen gaya dapat diartikan sebagai ukuran suatu gaya yang menyebabkan rotasi pada objek. Adapun besarnya momen gaya dihasilkan dari perkalian antara gaya dan lengan gaya (Hill, 2005). Lengan gaya merupakan jarak tegak lurus dari sumbu rotasi ke dalam garis kerja gaya (Giancoli, 2014). Gaya diukur dalam newton $(\mathrm{N})$, jarak diukur dalam meter, dan momen gaya diukur dalam newton meter $(\mathrm{Nm})$. Benda yang semula sudah berotasi akan mengalami perubahan kecepatan sudut apabila pada benda tersebut bekerja momen gaya (Abdullah, 2016).

d) Momen Inersia

Momen inersia adalah ukuran resistansi/kelembaman sebuah benda terhadap perubahan dalam gerak rotasi. Momen inersia ini tergantung pada distribusi massa, sumbu rotasi, bentuk, dan ukuran benda (Tipler, 2015). Sebagaimana fungsi massa pada gerak translasi yaitu ukuran kelembaman terhadap perubahan gerak, momen inersia juga mempunyai fungsi yang sama dalam gerak rotasi.

e) Hukum Kekekalan Momentum Sudut

Momentum sudur pada gerak rotasi disajikan dalam bentuk analogi dengan momentum linier pada gerak translasi. Apabila sebuah benda yang berotasi dengan momen inersia $I$ mempunyai kecepatan $\vec{\omega}$, maka momentum sudut $\vec{L}$ benda itu didefinisikan sebagai vektor:

$$
\vec{L}=I \vec{\omega}
$$


2) Ontologi Besaran-besaran Kesetimbangan Benda Tegar dan Dinamika Rotasi

Ontologi terkait dengan subjek atau realitas apa yang (dianggap) ada dan dapat dikaji atau diketahui (Purwanto, 2012).

a) Kesetimbangan Benda Tegar

Benda tegar dapat dikatakan berada dalam keadaan setimbang mekanis apabila percepatan linier $(a)$ dan percepatan sudut $(\alpha)$ benda tersebut besarnya sama dengan nol. Keadaan setimbang tersebut tidak mengharuskan benda berada dalam keadaan diam, tetapi bisa saja benda tersebut bergerak dengan kecepatan linier $(v)$ atau kecepatan sudut $(\omega)$ yang konstan. Keadaan setimbang semacam ini disebut sebagai keadaan setimbang dinamis, contohnya kipas angin. Sedangkan jika benda benar-benar dalam keadaan diam $(v=0$ dan $\omega=0$ ), benda dikatakan berada dalam keadaan setimbang statik.

b) Pusat Massa

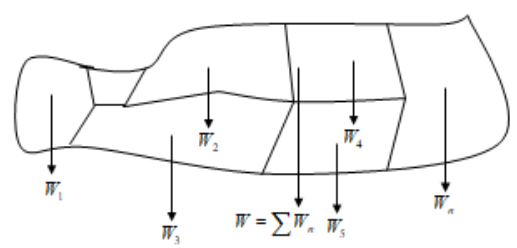

Gambar 2. Berat Semua Partikel sebuah Benda dapat diganti oleh Berat Total $W$ Benda yang Bekerja pada Pusat Massa

Gambar 2 menunjukkan sebuah benda dibagi menjadi beberapa benda yang lebih kecil, benda tersebut dapat dianggap sebagai partikel-partikel. Berat tiap partikel adalah $w_{i}$ dan berat total benda tersebut $W=\sum w_{i}$, sehingga titik tangkap gaya neto $X_{p b}$ dapat dinyatakan sebagai (Tipler, 2015):

$$
X_{p b} W=\sum_{i} w_{i} x_{i}
$$

c) Momen Gaya

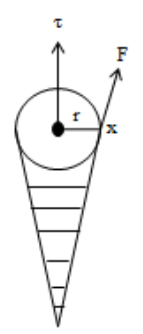

a) Arah momen gaya ke luar bidang



(b) Arah momen gaya masuk bidang

\section{Gambar 3. Arah Momen Gaya pada Mur}

Berdasarkan Gambar 3 sebuah mur memiliki arah perputaran yang searah dengan $r$ kemudian diberikan gaya $F$. Arah momen gaya $\tau$ ditentukan dengan aturan kaidah tangan kanan. Jika empat jari mengikuti arah perputaran lingkaran, maka arah ibu jari menunjukkan arah momen gaya $\tau$ sehingga arah momen gaya keluar dari bidang. Gambar $3 b$ menunjukkan 
arah $r$ kemudian diberikan gaya $F$ yang searah dengan perputaran jarum jam, sehingga arah momen gaya $\tau$ masuk bidang. Gambar 3a menunjukkan momen gaya bernilai negatif karena berlawanan dengan arah putaran jarum jam, sedangkan Gambar 3b menunjukkan momen gaya bernilai positif dikarenakan putarannya searah dengan arah perputaran jarum jam (Rosyid et al. 2015).

d) Momen Inersia

Suatu partikel bermassa $m$ dapat diabaikan diletakkan pada ujung tali berotasi membentuk lingkaran dengan radius $r$ dan terdapat satu gaya $F$ yang bekerja pada benda seperti pada Gambar 4.

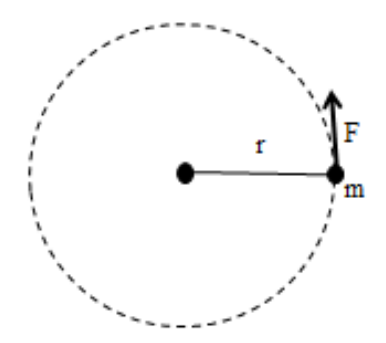

Gambar 4. Massa $m$ yang Berotasi pada Lingkaran dengan Radius $r$ terhadap Satu Titik yang Tetap

Torsi yang mengakibatkan percepatan sudut yaitu $\tau=r F$. Jika menggunakan hukum kedua Newton $\sum F=m a$, maka hubungan antara percepatan sudut dengan percepatan linier yaitu:

sehingga diperoleh:

$$
\begin{aligned}
a_{\text {tan }} & =\frac{\Delta v}{\Delta t} \\
& =r \frac{\Delta \omega}{\Delta t} \\
a_{\text {tan }} & =r \alpha
\end{aligned}
$$

$$
\begin{aligned}
& \vec{F}=m \vec{a} \\
& \vec{F}=m r \vec{\alpha}
\end{aligned}
$$

Jika dikalikan kedua sisi dengan $r$, maka torsi $\tau=r F$ dapat dinyatakan dalam persamaan berikut:

kuantitas $m r^{2}$ disebut dengan momen inersia.

$$
\vec{\tau}=m r^{2} \vec{\alpha}
$$

e) Hukum Kekekalan Momentum Sudut

Momentum sudut $L$ untuk sebuah benda yang berotasi sekitar sumbu yang tetap yaitu:

$$
\vec{L}=I \vec{\omega}
$$

dengan $I$ momen inersia dan $\omega$ kecepatan sudut. Satuan SI untuk $L$ adalah $\mathrm{kg} . \mathrm{m}^{2} / \mathrm{s}$ (Giancoli, 2014).

Syarat terjadinya hukum kekekalan momentum yaitu tidak adanya gangguan atau gaya dari luar yang memengaruhi momentum sudut.

3) Aksiologi Besaran-besaran Kesetimbangan Benda Tegar dan Dinamika Rotasi 
Aksiologi terkait dengan tujuan suatu ilmu pengetahuan, untuk apa (Purwanto, 2012). Ada beberapa jenis kesetimbangan statis untuk menghitung kesetimbangan stabil, tidak stabil, dan netral.

a) Kesetimbangan Stabil

Kesetimbangan stabil terjadi apabila torsi yang muncul karena perpindahan kecil dari benda tersebut memaksa benda itu kembali ke arah posisi kesetimbangannya (Tipler, 2015). Misalkan kelereng yang awalnya diam di dasar mangkok setengah bola, jika didorong sedikit sehingga bentuk posisi naik maka gaya beratnya memaksanya kembali ke arah posisi semula.

b) Kesetimbangan Tidak Stabil

Kesetimbangan tidak stabil terjadi apabila gaya-gaya atau torsi yang muncul karena perpindahan kecil dari benda memaksa benda menjauhi posisi kesetimbangannya (Tipler, 2015). Misalnya Sebuah bola yang sudah dikenai gangguan atau gaya jika gangguan pada benda dihilangkan maka benda tidak akan kembali ke posisi semula.

c) Kesetimbangan Netral

Kesetimbangan netral terjadi apabila tidak ada torsi atau gaya yang menggerakkannya ke salah satu arah (Tipler, 2015). Misalkan jika bola yang terletak pada lantai mendatar kasar diberi gaya kemudian dihilangkan maka bola awalnya akan bergerak dan suatu saat berhenti pada posisi yang berbeda.



Gambar 5: Gaya yang Bekerja pada Motor saat Melewati Tikungan

Gambar 5 menunjukkan seorang pembalap sedang mengendarai motor pada jalan yang menikung, sehingga dia bergerak secara melingkar. Efek yang ditimbulkan gaya ini adalah motor dapat terguling. Salah satu upaya yang dapat dilakukan agar motor tersebut tidak mengalami hal demikian maka harus menghasilkan reaksi penyeimbang dengan cara dimiringkan.

Perputaran sebuah roda disebabkan oleh adanya gaya gesekan antara roda dengan jalan. Karena gaya ini menyentuh permukaan roda maka keadaan tersebut menghasilkan momen gaya, sehingga mengakibatkan percepatan rotasi pada roda. Gaya gesekan antara roda dengan jalan merupakan gaya gesekan statik karena tidak ada gerak relatif antara permukaan roda dan jalan. Bagian permukaan roda turun di sisi depan, kemudian menempel di jalan, dan naik kembali di sisi belakang. Gaya gesekan kinetik akan terjadi pada roda yang selip karena ada gerak relatif antara permukaan jalan dan permukaan roda.

Apabila motor terguling maka ada rotasi antara titik kontak ban dengan jalan aspal ke arah luar. Gaya sentrifugal ini akan menghasilkan torsi saat motor berotasi ke arah luar jalan. Ketika motor dimiringkan ke dalam maka gaya berat menghasilkan torsi yang melawan dari torsi gaya sentrifugal. Jika kedua torsi tersebut sama besar maka motor dalam keadaan stabil, artinya dalam hal ini motor tidak mengalami terguling (rotasi keluar) dan pembalap tidak akan jatuh secara tiarap ke tanah (rotasi ke dalam) (Abdullah, 2016). 


\section{HASIL DAN PEMBAHASAN}

Penelitian ini merupakan pengembangan bahan ajar materi fisika kesetimbangan dan dinamika rotasi dengan pendekatan epistemologi, ontologi, dan aksiologi. Ada beberapa tahapan dalam pengembangan bahan ajar pada penelitian ini. Tahap pertama yang dilakukan adalah menganalisis permasalahan menurut studi pustaka yaitu salah satu materi yang dianggap sulit dipahami yaitu kesetimbangan dan dinamika rotasi. Selain itu bahan ajar yang ada belum pernah menggunakan ke-3 pendekatan tersebut.

Tahap kedua adalah pengumpulan data sesuai dengan permasalahan yang ada. Data yang diperoleh yaitu pedoman dalam pengembangan bahan ajar, kemudian pemilihan materi kestimbangan dan dinamika rotasi yang sesuai dengan kurikulum pendidikan. Tahap ketiga yaitu membuat desain bahan ajar. Pembuatan cover depan dan belakang menggunakan Corel Draw X5, sedangkan isi dalam bahan ajar menggunakan Microsoft Word 2010.

Tahap keempat yaitu validasi desain 1 yang dilakukan oleh validator ahli untuk menilai desain bahan ajar. Tahap kelima yaitu revisi desain 1 bahan ajar. Ada beberapa hal yang perlu direvisi diantaranya perbaikan typho penulisan, konsistensi pada halaman depan, konsistensi pengguaan tanda vektor, beberapa gambar rotasinya terlalu kecil, perlu ada latihan soal beserta kunci jawaban dan perlu ada glosarium. Tahap keenam yaitu validasi desain 2 bahan ajar yang dilakukan oleh validator ahli untuk menilai desain bahan ajar. Kemudian peneliti melakukan revisi tahap 2 dan dilanjutkan uji coba bahan ajar dengan skala terbatas, sehingga diperoleh produk akhir.

Kevalidan bahan ajar dengan pendekatan epistemologi, ontologi, aksiologi berdasarkan hasil skor rata-rata penilaian dari validator 1 dan 2 yang berdasarkan kelayakan isi, kebahasaan, kegrafisan dan penyajian. Hasil uji kelayakan bahan ajar dapat dilihat pada tabel 3 .

Tabel 3. Hasil Penilaian Validasi Bahan Ajar

\begin{tabular}{cccccc}
\hline \multirow{2}{*}{ No } & \multirow{2}{*}{$\begin{array}{c}\text { Aspek yang } \\
\text { dinilai }\end{array}$} & \multicolumn{2}{c}{ Validator } & Rata-rata & \multirow{2}{*}{ Kategori } \\
\cline { 3 - 4 } & $\mathbf{V}_{\mathbf{1}}(\mathbf{\%})$ & $\mathbf{V}_{\mathbf{2}}(\mathbf{\%})$ & $\mathbf{( \% )}$ & \\
\hline 1 & Kelayakan isi & 66,67 & 93,33 & 80,00 & Layak \\
2 & Kebahasaan & 70,00 & 100 & 85,00 & Sangat layak \\
3 & Kegrafisan & 70,00 & 80,00 & 75,00 & Layak \\
4 & Penyajian & 73,33 & 93,33 & 83,33 & Sangat layak \\
\hline & Rata-rata & 70,00 & 91,66 & 80,83 & Layak \\
\hline
\end{tabular}

Aspek penilaian pada kelayakan isi meliputi kesesuaian indikator dengan bahan ajar, kebutuhan pencapaian kompetensi dan tujuan pembelajaran. Hasil validasi pada aspek ini dapat dilihat pada Tabel 3 diperoleh nilai rata-rata sebesar 80,00 dengan kategori layak. Hal ini sejalan dengan penelitian dilakukan oleh Daryanto (2015) menyatakan bahwa salah satu karakteristik dari bahan ajar yaitu self contained, maksudnya jika seluruh materi pembelajaran yang dibutuhkan semua termuat. Tujuan dari konsep ini yaitu untuk memberikan kesempatan pada peserta didik mempelajari materi pembelajaran secara tuntas. Adanya bahan ajar ini akan membantu tercapainya tujuan pembelajaran yang ingin dicapai.

Aspek kebahasaan meliputi kesesuaian keterbacaan, PUEBI (Pedoman Umum Ejaan Bahasa Indonesia), kejelasan informasi dan penggunaan bahasa. Berdasarkan data pada Tabel 3 diperoleh nilai riata-rata aspek kebahasaan sebesar 85,00 dengan kategori sangat layak. Hal ini sejalan dengan Yumma et al. 2018 menyatakan bahwa bahasa yang digunakan sesuai dengan tingkat perkembangan peserta didik, komunikatif dan kaidah PUEBI. Salah satu karakteristik suatu bahan ajar yaitu mudah dioperasikan/dipakai oleh pengguna (user friendly) berarti bahwa setiap instruksi dan paparan informasi yang tampil bersifat membantu dan bersahabat dengan pemakainya. Ada beberapa hal yang termasuk dalam user friendly yaitu penggunaan bahasa yang sederhana, mudah dimengerti, dan menggunakan istilah umum 
yang digunakan dalam bahan ajar (Daryanto, 2015). Dari penjelasan tersebut, maka dapat disimpulkan bahwa bahan ajar materi fisika dengan pendekatan epistemologi, ontologi dan aksiologi layak digunakan untuk pembelajaran.

Selanjutnya aspek kegrafisan terdiri dari keruntutan dan sistematika langkah-langkah kegiatan, kejelasan gambar dengan tulisan, kesesuaian gambar dengan materi dan struktur desain buku. Berdasarkan data hasil validasi, aspek kegrafisan memperoleh nilai rata-rata sebesar 75,00 dengan kategori layak. Penelitian ini sejalan dengan Rahmatina et al. (2020) menyatakan bahwa bahan ajar dengan desain tampilan yang menarik serta pemilihan ilustrasi dapat mempermudah dalam memahami materi, sehingga peserta didik akan tertarik untuk belajar. Dapat dikatakan bahwa bahan ajar ini layak digunakan untuk penelitian.

Aspek penyajian bahan ajar meliputi relevansi bahan ajar dengan KI (Kompetensi Isi), KD (Kompetensi Dasar), standar isi, kesesuaian langkah penyajian materi, penyajian gambar, ilustrasi dan desain mempertimbangkan kebermanfaatan. Berdasarkan hasil data validasi aspek penyajian memperoleh nilai rata-rata sebesar 83,33 dengan kategori sangat layak. Bahan ajar ini dapat dipakai untuk penelitian, karena penyajian materi, gambar sudah sesuai dengan pendekatan epistemologi, ontologi dan aksiologi. Hal ini sejalan penelitian yang dilakukan oleh Rahmatina et al. (2020) menyatakan bahwa penyajian bahan ajar sangat diperlukan dalam menanamkan pengetahuan sehingga kegiatan proses pembelajaran akan menjadi bermakna.

Berdasarkan data pada Tabel 1 diperoleh informasi secara keseluruhan rata-rata hasil uji kelayakan bahan ajar dari validator 1 dan 2 diperoleh sebesar 80,83 dengan kategori layak. Dari hasil tersebut dapat dikatakan bahwa bahan ajar dengan pendekatan epistemologi, ontologi, dan aksiologi layak untuk digunakan penelitian. Hal ini sejalan dengan Akinbobola (2015) menyatakan bahwa bahan ajar yang baik dapat dianggap sebagai alat utama dalam kemajuan pendidikan suatu negara dan pembangunan nasional. Secara filosofis, kegiatan pembelajaran peserta didik harus memenuhi aspek epistemologi, ontologi, dan aksiologi dalam memperoleh ilmunya di sekolah (Jauhariyah \& Supriyono, 2017). Mengingat pentingnya bahan ajar, maka diharapkan melalui pembelajaran peserta didik dapat memahami materi kesetimbangan dan dinamika rotasi lebih detail. Gambar 6.

Adapun hasil respons peserta didik terhadap penilaian bahan ajar dapat dilihat pada

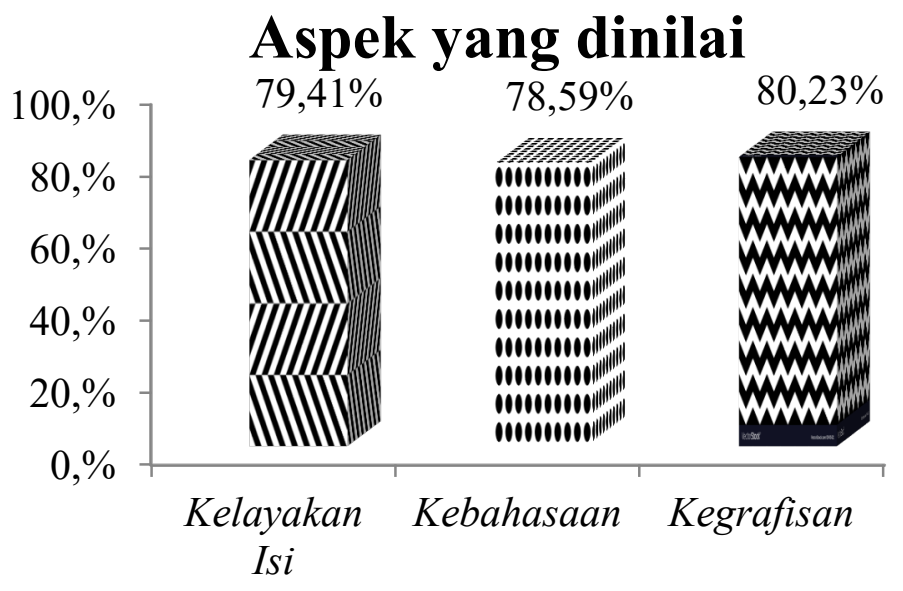

Gambar 6. Persentase Data Angket Respons Peserta Didik

Berdasarkan uraian data pada gambar 1 diperoleh informasi hasil keseluruhan angket respons peserta didik terhadap penggunaan bahan ajar tentang kesetimbangan dan dinamika rotasi dengan pendekatan epistemologi, ontologi dan aksiologi memperoleh nilai rata-rata 
sebesar 79,41\% dengan kategori setuju. Hasil ini menunjukkan bahwa bahan ajar yang dikembangkan dalam penelitian ini layak untuk digunakan (Sofyan et al. 2019).

Ketika proses pembelajaran berlangsung, peserta didik tidak hanya dapat memahami konsep-konsep fisika, tetapi dapat juga memahami penerapan kesetimbangan dan dinamika rotasi dalam kehidupan sehari-hari. Hal ini sejalan dengan penelitian yang dilakukan oleh Sugianto et al. (2018) yang menyatakan bahwa isi bahan ajar dapat dipahami oleh peserta didik dengan baik, desain menarik dan bersifat matematis sehingga tidak mengalami kebosanan saat kegiatan pembelajaran berlangsung. Daryanto (2013) menjelaskan bahwa bahan ajar yang memuat seperangkat pengalaman berencana terencana, dikemas secara sistematis dan didesain untuk membantu siswa menguasai tujuan belajar secara khusus. Dengan demikian bahan ajar materi fisika tentang kesetimbangan dan dinamika rotasi dengan pendekatan epistemologi, ontologi, aksiologi mendapatkan respons setuju dari peserta didik dan tertarik untuk menggunakannya saat pembelajaran.

\section{KESIMPULAN}

Bentuk pengembangan bahan ajar materi kesetimbangan dan dinamika rotasi dengan pendekatan epistemologi, ontologi, aksiologi melalui beberapa tahapan yaitu potensi dan masalah, pengumpulan data, desain produk, validasi desain 1, revisi tahap 1, validasi desain 2, revisi tahap 2, uji coba terbatas dan produk akhir. Hasil validasi bahan ajar yang dilakukan oleh validator 1 dan 2 didapatkan rata-rata 80,83\% dengan kategori layak. Respons peserta didik terhadap penggunaan bahan ajar tentang materi kesetimbangan dan dinamika rotasi pada kelas XI MIPA 3 yang telah dikembangkan dalam pembelajaran memperoleh nilai ratarata sebesar 79,41\% dengan kategori setuju. Dengan demikian, bahan ajar dengan pendekatan epistemologi, ontologi, dan aksiologi dapat digunakan untuk pembelajaran.

\section{DAFTAR PUSTAKA}

Abdullah, M. 2016. Fisika Dasar 1. Institut Teknologi Bandung.

Adib, M. 2018. Filsafat Ilmu Ontologi, Epistemologi, dan Logika Ilmu Pengetahuan, Edisi ke-3 (Revisi). Yogyakarta: Pustaka Pelajar.

Akinbobola, A. O. 2015. Guidelines on How to Read a Physics Textbook and the Assessment of the Readability of Recommended Physics Textbooks in Secondary Schools in Osun Satte of Nigeria. Journal of Education and Practice. Vol. 6 No. 6.

Alelaiment, A. R., \& Ghoneem, K. A. A. R. 2012. The Effect of Educational Modules Strategy on the Direct and Postponed Study's Achievement of Seventh Primary Grade Students in Science, in Comparison with the Conventional Approach. Higher Education Studies. Vol. 2 No. 2.

Alias, N., Siraj, S., Dewitt, D., Attaran, M. dan Nordin, A. B. 2013. Evaluation on the Usebility of Physics Module in a Secondary in Malaysia: Students' Retrospective. The Malaysian Online Journal of Educational Technology. Vol. 1 Issue1.

Arikunto. 2010. Prosedur Penelitian. Jakarta: Rineka Cipta.

Daryanto. 2013. Menyusun Modul Bahan Ajar Untuk Persiapan Guru Dalam Mengajar. Yogyakarta: Gava Media.

Giancoli, D. C. 2014. Fisika Prinsip dan Penerapannya, Edisi Ketujuh Jilid 1. Jakarta: Erlangga.

Hill, M. 2005. Physics Principles and Problems. United States of America.

Jauhariyah, M. N. R. \& Suproyono, S. 2017. Pengembangan Buku Ajar Telaah Kurikulum Sekolah untuk Mahasiswa Program Studi Pendidikan Fisika Universitas Negeri Surabaya. Prosiding Seminar Nasional Fisika (SNF). Vol. 1. 
Kiong, T. T., Yunos, J. M., Mohammad, B., Othman, W., Heong, Y. M., \& Mohammad, M. M. 2012. The Development and Implementation of Buzan Mind Mapping Module. Procedia Social and Behavioral Science 69. 705-708.

Prayekti. 2017. The Development of Open University New Generation Learning Model Using Research and Development for Atomic Physics Course PEFI4421.World Journal of Education. Vol. 7 No. 5.

Purwanto, A. 2012. Nalar Ayat-Ayat Semesta Menjadikan Al-Quran sebagai Basis Konstruksi Ilmu Pengetahuan. Mizan: Bandung.

Rahmatina, C. A., Jannah, M. \& Annisa, F. 2020. Pengembangan Bahan Ajar Berbasis Science, Technology, Engineering and Mathematics (STEM). Jurnal Pendidikan Fisika dan Fisika Terapan. Vol.1 No. 4. Hal 20-26.

Riduwan. 2013. Skala Pengukuran Variabel-Variabel Penelitian. Bandung: Alfabeta.

Rosyid, F. M., Firmansyah, E., \& Prabowo, D. Y. 2015. Fisika Dasar, Jilid 1: Mekanika. Periuk: Yogyakarta.

Sarkity, D., Yuliati, L., \& Hidayat, A. 2016. Kesulitan Siswa SMA dalam Memecahkan Masalah Kesetimbangan dan Dinamika Rotasi. Vol. 1. Pros. Semnas Pend. IPA Pascasarjana UM. ISBN: 978-602-9286-21-2.

Sofyan, H., Anggereini, E., \& Saadiah, J. 2019. Development of E-Modules Based on Local Wisdom in Central Learning Model at Kindergartens in Jambi City. European Journal of Educational. Vol. 8 Issue 4. Number: 1137-1143.

Sugiyono. 2012. Metode Penelitian Pendidikan (Pendekatan Kuantitatif, Kualitatif, dan $R$ \& D). Bandung: Alfabeta.

Sumarto. 2017. Filsafat Ilmu. Jambi: Pustaka Ma'arif Press.

Tipler, A. P. 2015. Fisika untuk Sains Teknik Edisi Ketiga Jilid 1. Jakarta: Erlangga.

Toharudin, U., Hendrawan, S., dan Rustman, A. 2011. Membangun Literasi Peserta Didik. Bandung: Humaniora.

Yumma, A., Fauzi, A., \& Yulkifli. 2018. Validity of Flood Themed Science Textbook for Junior High School with Sequenced Model Using Problem-Based Learning. International Conference on Research and Learning of Physics. Doi: 10.1088/17426596/1185/1/012129. 